Oksana Lytvyn, lector

Pavlo Tychyna Uman State Pedagogical University 2, Sadova str., Uman, Cherkasy region, 20300, Ukraine, ORCID: 0000-0003-2616-468X ResearcherID: D-6763-2019

\title{
OVERTOURISM PROBLEMS IN FORMING INTERNATIONAL TOURIST FLOWS
}

At the beginning of the XXI century the world of tourism underwent the fundamental changes. They are related to the development of information technology, development of transport infrastructure, cheaper tours, which in turn lead to an increase in the number of travelers every year. But there is a problem of uncontrolled demand and high concentration of tourists, which has a negative impact on individual tourist regions and the local population. Increasing tourist flows and increasing demand for tourist destinations creates a global problem.

Keywords: tourism, mass tourism, overtourism, tourist flows, destinations.

Actuality of theme is proved by research which was made to order UNWTO in 2017 «Overtourism? Understanding and managing urban tourism growth beyond perceptions» [2].

Formulation of the problem It is revealed that the problems of uneven distribution of tourist flows have a negative impact on the natural, socio-cultural, political and economic features of tourist destinations.

Analysis of recent research and publications An analysis of recent research and publications on this topic has revealed that this topic in Ukraine is not well developed yet. The problems of sustainable development of urban tourism and overtourism are devoted to the work of foreign and domestic scientists, such as: Dedok V. M., Smyrnov I. H.

Setting objectives Investigation of the impact of tourist flows on the development of tourist regions, assessment of possible problems and threats of overtourism for tourist centers.

Presenting main material Overtourism is a new phenomenon in tourism. This term has emerged recently, but is gaining popularity because of the «oversaturation» of certain tourist destinations by tourists, which has a negative impact on tourist sites, local communities and their way of life. So popular places overwhelm tourist streams, shaping the destruction and destruction of historical and natural monuments. 
Overtourism is a modern phenomenon of mass tourism that has negative consequences. It is associated with an increase in the number of air carriers, a decrease in the cost of rented housing and the increasing popularity of individual locations. The expanse of the tourists number increases the consumption of natural and tourist resources, puts socio-cultural pressure on infrastructure. Therefore, some countries try to limit the flow of tourists, even if they bring additional revenue to the budget. Defining and creating mechanisms for monitoring and managing tourist flows and congestions, tourist capacities of territories and parameters of necessary changes, it is advisable to use quantitative and qualitative indicators to obtain a comprehensive expression of tourist influence on the destination in the conditions of overtourism. The following features of the phenomenon of overtourism in cities should be taken into account:

1. When it comes to tourist congestion of the city, it means not so much the number of tourists, but the tourist capacity to accommodate them. Yes, there are cities that successfully cope with numerous tourists, while others can not afford much less tourist flows.

2. The tourist congestion is usually more local than city-wide. Excessive tourist pressure is felt mainly in the central, most popular areas of cities with a high concentration of tourist attractions. Therefore, in the search for a solution to the problem of overtourism, it is necessary to analyze the territorial distribution of tourist flow in the city with the identification of places and causes of tourist congestion.

3. Urban congestion in cities is not always related to tourism alone. The phenomenon of overtourism is particularly noticeable when the city's resources and infrastructure are under pressure. However, not only tourists create this pressure, but local residents and visitors alike compete with them. This is especially felt in the area of rental housing, where for renting accommodation (hotels, apartments, hostels) tourists compete with local demand.

4. Using of technological and smart solutions is important in tackling urban overtourism, but it will not be effective without combination with other approaches. Yes, smart technologies are considered to be the most suitable for solving the problem of excessive tourist flows in cities, but without taking into account the challenges posed by the urgency of urban tourism in the sense of close cooperation of many participants in the long term, the solution will be ineffective [5].

The World Tourism Organization has introduced the concept of the capacity of a territory with the maximum number of visitors, who may be in the same period in one tourist place or region, but without causing damage to the physical, ecological and socio-cultural environment and to maximize the effect of the trip.

There are four aspects related to bandwidth of the territory:

1) the problem of large numbers of tourists in a certain area concerns not only their number but also the ability to manage them;

2) this problem does not affect the whole city, but only certain areas;

3 ) the bandwidth problem is often associated not only with tourism, but also with a comprehensive approach that takes into account the city's development strategy; 
4) the use of modern technologies to manage the large number of tourists is an important but insufficient tool for solving the problem of congestion, long-term cooperation of numerous stakeholders is needed [7].

Today, tourism accounts for a share of global GDP 10,4\%, in 2018 year industry growth was 3,9\% compare to 3,4\% growth of total world GDP. According to the World Tourism and Travel Council, 319 million people worldwide are involved in tourism, accounting for $1 / 5$ of the number of jobs created in the last 5 years. The huge chunk of turnover -on holiday tourism (78,5\%), others $21,5 \%$ - business tourism, moreover, international tourism has a share $-28,8 \%, 71,2 \%$ - internal movements. It is estimated that the number of travelers will increase every year, as will the number of specialists involved in this field (agents, representatives of the hotel and restaurant business, transport infrastructure, etc.), by 2029 their number will be approximately 154 million.

International company Statista published the rating of the European cities most suffering from overtourism. Calculating the rating, the following indicators were taken into account: the number of tourists who arrived to the city by flights; the number of beds available per square kilometer; ratio of the number of tourists in peak season to the number of locals; the feedback from the locals of each city about the tourists and whether they feel discomfort with the tourist flows. The cities were rated from 10 (tourists do not disturb the locals at all) to 1 (tourists are a big problem for the locals). With this scale, Barcelona (Spain) ranked highest in the ranking with a score of 2.05 points. Second and third place went to Amsterdam (Netherlands) - 2.18 points and Venice (Italy) - 2.19 points. Next in popularity are Milan (Italy) and Budapest (Hungary) with 2.66 and 2.89 respectively. [4].

Overtourism, as a rule, is the capitals and major cities of developed countries. But the influx of tourists also suffer from small villages. The Austrian village Hallstatt, which became the prototype of the Erendel Kingdom in the cartoon «Cold Heart». S. Hallstatt has always been popular with tourists due to its picturesque scenery. However, in the last 10 years the number of visitors has increased 100 times! In 2009, the village was visited by 100 people a day, then in 2019 , to see all the landscapes want to 10 thousand visitors a day. At the same time, in the village live 780 people. Local authorities are trying to reduce the flow of tourists by a third by reducing the amount of transport people get to these places. Note that Hallstatt was included in the UNESCO World Heritage List in 1997. There is the world's oldest salt mine in Hallstatt, dating back to 7,000 years. Also in the village are preserved houses of the fourteenth century and the Lutheran church [8].

Is there an overtourism problem in Ukraine? In recent years, the largest tourist centers of Ukraine in Kyiv, Odessa, and Lviv have experienced the problem of overtourism. For example, in Lviv, «The concept of tourism decentralization» was developed within the framework of the "City Tourism Development Strategy until 2021» [6]. In particular, this concept involves the use of architectural and related intangible cultural heritage in the course of the tourist «unloading» of the city center of 
Lviv (Market Square and Svobody Avenue) through vertical and horizontal diversification of tourist flows.

Due to the powerful tourist flow to the Carpathian National Nature Park a fee is set here, which ranges between 10-20 UAH, for visiting 5 territories - waterfall Guk, aviary farms, ecotourism visit center, ecological and educational route «Dovbush Path» and Hoverla. The money goes to the park for the arrangement and care of tourist routes, improvement and development of infrastructure.

The trend of event travel, which is beginning to develop in Ukraine, is gaining momentum. For example, Zaporizhzhia also goes to festival tourism. Particularly overtourism is observed in the period from April to August on Khortytsia Island, near the Cossacks Museum, Zaporizhia Sich, Horse Theater [3, p. 29].

It should be noted that there are different approaches to solving this problem, such as the introduction of additional taxes and penalties, raising existing taxes, limiting the number of visitors, introducing special permits to visit tourist sites, etc. [1].

Conclusions. In order to minimize the impact of overtourism on the tourist region, it is necessary to develop, implement and control measures to eliminate it. Of particular importance is the assessment and control of tourist load on the destinations, taking into account the individual features of the territories, taking into account the segmentation of tourists, the introduction of quotas for visits to popular tourist sites.

\section{REFERENCES}

1. Dedok V. M. (2018) Overtourism and its consequences: international experience. Retrieved from: http://elib.bsu.by/bitstream/123456789/239654/1/317-323.pdf

2. Overtourism? Understanding and Managing Urban Tourism Growth beyond Perceptions. UNWTO Library. (2018). URL https://www.e-unwto.org/doi.pdf

3. Petryshyn D. R. \& Rutynskyi M. Y. (2019) World phenomenon of overtourism and ways of overcoming it. Potential threat to domestic tourist destinations. Tourism brand as a factor of formation of a positive image of Ukraine in the world market: Proceedings of the Ukrainian Scientific and practical Internet conference, pp. 28-30.

4. Ranking of the worst cities for over-tourism in Europe in 2018. Retrieved from: https://www.statista.com/statistics/778687/overtourism-worst-european-cities/

5. Smyrnov I. H. (2019) Geologistic strategies of tourist and hotel and restaurant business development in overtourism conditions. Scientific bulletin Kherson state university, Vol. 10, pp. 86-96.

6. Smyrnov I. H. \& Liubitseva O. O. (2019) Marketing of sustainable tourism. Kyiv: Lira-K

7. World Tourism Organization (2018), Overtourism? Retrieved from: https:// www.e-unwto.org/doi/abs/10.18111/9789284421084

8. Where tourists are not happy: the village-prototype of the kingdom of the «Ice Heart» suffers from overtourism. Retrieved from: https://ravel.tochka.net/ ua/14690-gdeturistam-ne-rady-poselok-prototip-korolevstva-iz-ledyanogo-serdtsa-stradaet-ot-overturizma/ 